\title{
Conservation in the Pantanal of Brazil
}

\author{
Russell A. Mittermeier, Ibsen de Gusmão Câmara, Maria Tereza Jorge Pádua \\ and Janice Blanck
}

The Pantanal of South America is the world's largest wetland and has an abundant and diverse fauna. Although man's influence has caused many changes there are still some little disturbed areas, which offer opportunities for conservation. The authors discuss some of the threats to the region and recommend how these could be mitigated.

The Pantanal region of Brazil and adjacent portions of Paraguay and Bolivia (Figure 1) covers $110,000 \mathrm{sq} \mathrm{km}$. It consists mainly of the low altitude (100 $\mathrm{m}$ a.s.l.) floodplain of the Rio Paraguay and its tributaries, which drop off the planalto (inland plateau) of central Brazil. It is bordered to the east by cerrado (savannah) formations of the planalto, to the north-west by the semi-deciduous forest of the transition zone between Amazonia and cerrado, and to

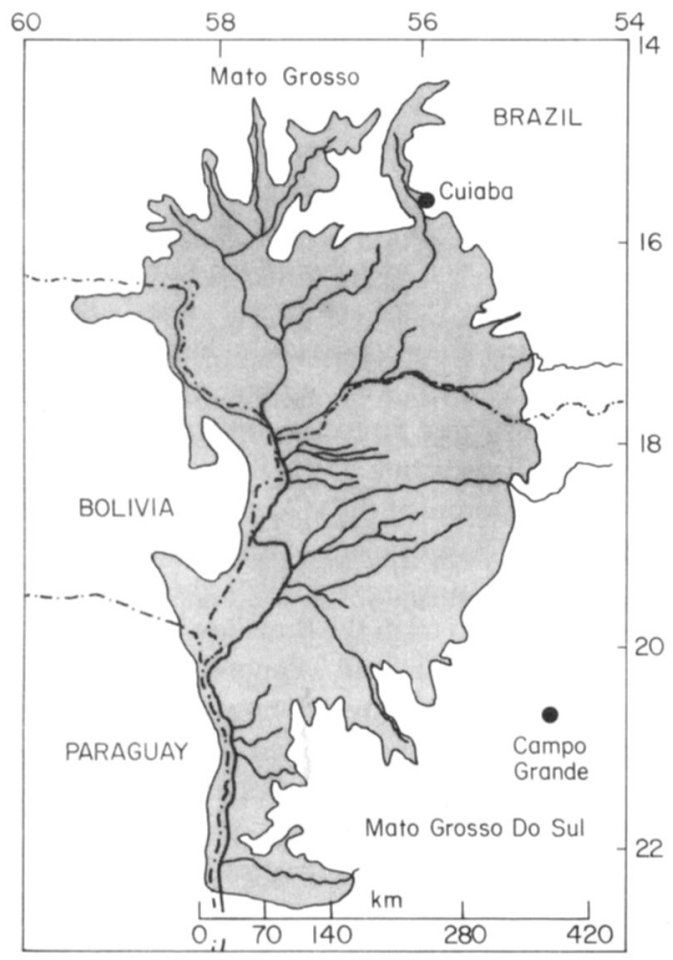

Figure 1. Map showing the location of the Pantanal. the south-west by the dry chaco formations of Bolivia and Paraguay (Prance and Schaller, 1982). The vegetation includes elements from all these formations, and is a diverse mosaic of swamp, gallery forest, lake margin scrub forest, semi-deciduous forest, and several different kinds of cerrado and savannah (Prance and Schaller, 1982). Much of the area is flooded from December to June, and there are large, permanently flooded areas (including lakes up to $100 \mathrm{sq} \mathrm{km}$ in extent, mainly in the northwestern part of the region). Due to gradual land declination from east to west, the extent of flooding increases approaching the Paraguay River. Rainfall is $1000-1300 \mathrm{~mm}$ per annum, most of it falling between December and March.

The principal economic activity is cattleraising, which was introduced at the end of the last century, and most of the land is owned by large fazendeiros (ranch-owners), a number of whom have tracts exceeding $1000 \mathrm{sq} \mathrm{km}$. Cattle-raising and associated burning of grasslands in the dry season have greatly affected the vegetation, and it is believed that little of the Pantanal's vegetation remains undisturbed. Nonetheless, cattle-raising here is far less destructive than in Amazonia, where large-scale clear-cutting of forest is the usual method of preparing land for cattle pasture. The Pantanal has large areas of natural grassland, there has been relatively little felling and large tracts remain with very low human and cattle population densities. There is still an opportunity to conserve a major portion.

Other economic activities include: fishing, which is being carried out at what appear to be unsustainable levels; tourism, which is 


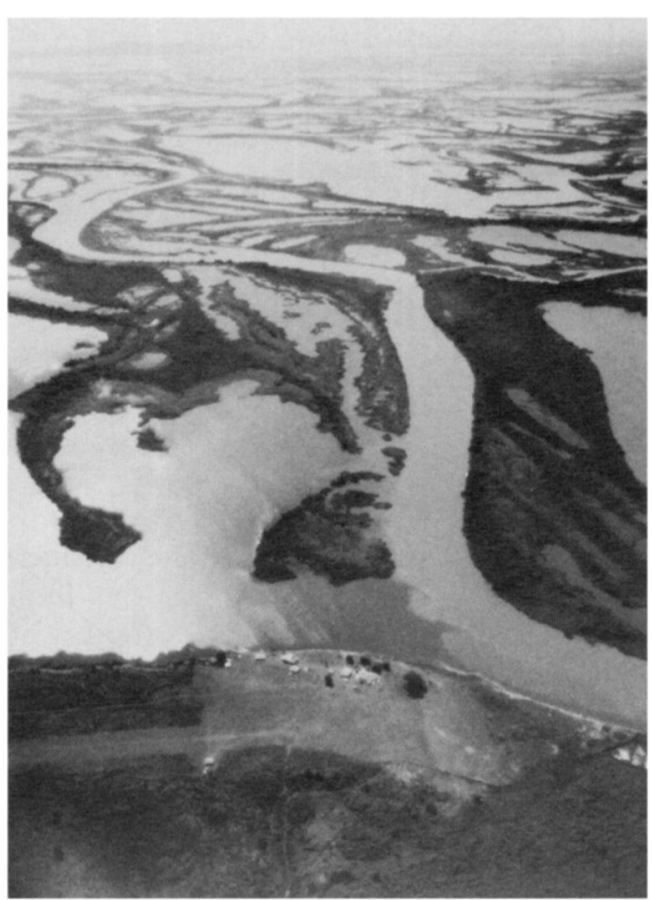

Aerial view of the Pantanal in the month of August (Russell A. Mittermeier).

growing rapidly; and illegal hunting of caimans.

The Pantanal has an abundant fauna and is probably the most important area in South America for wetland birds. Other bird species include the rhea Rhea americana, the southern screamer Chauna torquata and a variety of psittacines, most notably the hyacinth macaw Anodorhynchus hyacinthinus. The Pantanal is an important migratory bird stopover point and wintering ground, and it falls within three migratory routes: the Central Brazil, Rio Negro and the Cis-Andean (Sick, 1983).

The Pantanal is also known for its abundance of mammal and reptile species. Capybara Hydrochoerus hydrochaeris are quite common and are easily observed in the dozens or even hundreds, whereas species such as tapir Tapirus terrestris, jaguar Panthera onca palustris and puma Felis concolor, which are quite difficult to see in the wild, are more likely to be encountered here than anywhere else within their range. Indeed, the Pantanal must be considered a major stronghold for a number of ma.nmal species, jaguar and marsh deer Blastocerus dichotomus, for example. The maned wolf Chrysocyon brachyurus and the giant anteater Myrmecophaga tridactyla, which are rapidly disappearing in other parts of their range, accompanied by the highly endangered giant otter Pteronura brasiliensis, maintain a tenuous existence in the Pantanal. Monkeys are not a highly conspicuous element of the Pantanal fauna, but five or six species occur there. The most abundant is the black howler monkey Alouatta caraya, which lives in larger forest tracts and also in very narrow bands of seasonally flooded gallery forest, although this must be considered marginal habitat for a Neotropical primate. The tufted capuchin Cebus apella is probably the next most abundant species and the black-tailed marmoset Callithrix argentata melanura, the titi monkey Callicebus moloch and at least one and probably two species of night monkey, Aotus azarae and A. infulatus, occur at the edges of the Pantanal, especially in the north.

The most obvious reptile is the Paraguayan caiman Caiman crocodylus yacare. Although large aggregations can still be seen, the estimated annual caiman poach of 1 million skins (Gaski and Hemley, 1988), has led to the near extermination of the species in some areas.

There are two government protected areas in the Pantanal: the 112-sq-km Taiamã Ecological Station and the 137-sq-km Pantanal National Park. These are almost entirely inundated during the wet season, when terrestrial animals have to seek refuge outside their boundaries. These protected areas were created under the jurisdiction of the Special Secretariat for the Environment (SEMA) and the Brazilian Forestry Development Institute (IBDF), respectively. In February 1989 the organizations merged to form the Brazilian Institute for the Environment and Renewable Natural Resources (IBAMA), which now holds responsibility for Brazil's protected areas. In April 1989, Chapada dos Guimãeres, in the planalto region north-west of Cuibá, was declared a national park. It is largely cerrado and gallery forest and its $340 \mathrm{sq} \mathrm{km}$ protect some of the tributary headwaters that fall into the Paraguay River Basin. 


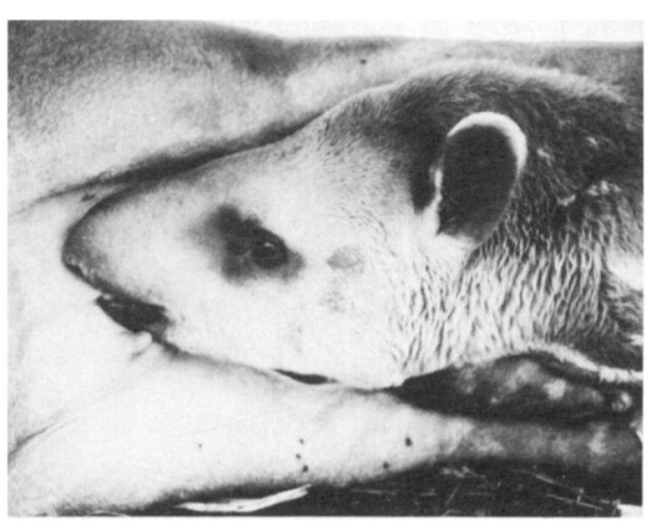

A young tapir suckling. Except for females with young, tapirs are solitary animals and quite difficult to see in the wild (Russell A. Mittermeier).

\section{Threats to the Pantanal}

The threats facing the Pantanal can be divided into two categories: threats from outside the region in the form of activities that adversely affect the rivers that feed it, and threats from within the Pantanal itself.

\section{Threats from outside the Pantanal}

Deforestation and siltation. Deforestation and burning of forests at the headwaters of rivers feeding the region result in widespread erosion and siltation. For example, in the 1970s the Development Programme for the Cerrado Region (POLOCENTRO) encouraged agricultural expansion throughout the planalto on the edge of the Pantanal and more than $40 \mathrm{sq}$ $\mathrm{km}$ of cerrado were deforested, including gallery forests along the Taquari, Sao Lourenço and Cuiabá rivers, all important tributaries of the Paraguay River (Figure 1). Rice was planted and the heavy tractors used to prepare the soil compacted the subsoil, impeding penetration of rainfall, which resulted in large quantities of topsoil being eroded. The National Department of Sanitation and Public Works in Brazil (DNOS) estimated that in 1982, 3500 tons of soil were carried to the Pantanal from the Taquari River alone. This deforestation was repeated along the Aquidauana, Miranda and Bonito rivers. Excessive siltation and erosion of river beds caused by adjacent deforestation in elevated regions already appears to be affecting the region's drainage. In March 1989, there was an estimated $1 \mathrm{~m}$ of standing water above parts of the Transpantaneira Highway (a dirt road, which transects the northern Pantanal of Mato Grosso), never seen before in the Pantanal. People from the southern Pantanal of Mato Grosso do Sul talk about how flooding patterns have changed in recent years, noting that even with steady rainfall patterns throughout the wet season, there seems to be less flooding during November, December, January and February, and much heavier flooding in March and April.

Pollution. Toxins used in agricultural projects outside the Pantanal wash into the rivers flowing into the region and have an adverse effect on the fish and other aquatic life.

In soybean fields, which cover a large portion of the cerrado terrain on the periphery of the Pantanal, herbicides and insecticides are used. These chemicals are washed away with the rains, increasing water pollution in the Pantanal. Fish kills attributed to toxins in the water have considerably reduced some fish stocks (E. Resende, pers. comm.). A large portion of the Pantanal's fauna, not to mention its people, depend on fish as a source of food.

The Cuiabá River, an upper tributary of the Paraguay River, passes through the city of Cuiabá (population approximately $1,000,000$ ) where it receives various kinds of domestic and industrial waste before reaching the Pantanal.

Although waste from alcohol distilleries just outside the Pantanal once threatened the region's rivers, it is now being used to produce fertilizer, and pollutants from this industry are minimal. There are nine distilleries in Mato Grosso (six of which are currently in operation) and two in Mato Grosso do Sul. The latter state has a law prohibiting construction of further distilleries.

North of the Pantanal iron ore mines wash ore stacks with detergent, allowing the runoff to flow into streams and rivers where it forms a thin film on the water surface and impedes oxygen transfer, suffocating life below. 


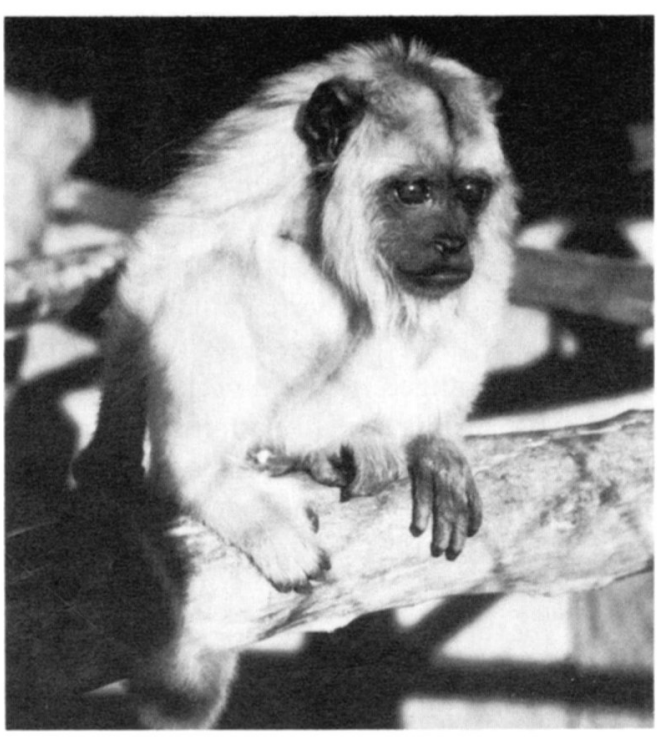

Juvenile black howler monkey, one of the few primates in the Pantanal (Russell A. Mittermeier).

Gold-mining. In the mid-1980s gold was discovered at the edge of the Pantanal in Mato Grosso near Poconé, and gold-mining has been in operation since. Mining presents a number of threats including considerable siltation and erosion that result from dredging river banks and bottoms, and pollution from the mercury used to separate out the gold. The state of Mato Grosso ranks second, behind Pará, in Brazil's gold production. In 1985, both the Couros and Agua Branca rivers, which feed the Coxipó River, a tributary to the Cuiabá River, were discovered to be absent of life because of pollution from mining activities. In recognition of the great threat presented by gold mining, the Governor of Mato Grosso is taking steps to eliminate mining from the region.

International animal and skin trade. Hyacinth macaws, which have a market value of up to $\$ 8000$ a pair in the USA and $\$ 15,000$ in Europe, are smuggled out of the Pantanal for the pet trade. A recent survey indicated that a maximum of 3000 individuals remain in the wild, and that 50 per cent of all smuggling in Brazil is for the national market (J. Thomsen, pers. comm.).
In June 1985, the (now defunct) IBDF, the federal agency responsible for wildlife legislation and enforcement at that time, confiscated a shipment of animal skins at Viracópolos International Airport in São Paulo. The shipment contained 70,000 skins of jaguars, maned wolves, foxes (Dusicyon spp), caimans and snakes (e.g. Constrictor constrictor). This cargo weighed $2500 \mathrm{~kg}$ yet represented only 13 per cent of the $18,800 \mathrm{~kg}$ of skins that had been sent to Germany by the smugglers 6 months previously. Many of the skins were probably from the Pantanal, where poaching of this magnitude is not uncommon and dramatically alters ecosystem dynamics (Alho et al., 1988).

\section{Threats from within the Pantanal}

Drainage. The most serious internal threat to the Pantanal is land drainage for agriculture and cattle ranching. In one area of Mato Grosso, near Poconé, a dike has been built around an area of some $1000 \mathrm{sq} \mathrm{km}$, completely modifying the water regime. If this practice is adopted by other landowners in the region, the results could permanently alter the Pantanal.

Commercial overfishing. Commercial fishing is a serious threat, especially in the large permanent lakes (e.g. those near Barão de Melgaço), where fish are caught in enormous numbers during the breeding season. Huge nets, some of them $1 \mathrm{~km}$ long, are placed in the mouths of these lakes and catch almost everything. Commercial fishing with refrigerated boats and trucks takes out large quantities of fish for sale in São Paulo and other cities. The greatest weight of fish taken are of pacu Colossoma mitrei, two species of surubim (catfish), cacharra $P$ seudoplatystoma fasciatum and pintada $P$. corruscans, curimbata Prochilodus lineatus and dourado Salminus maxillosus. Trucks are often seen along the Transpantaneira Highway with three or four large launches attached. These are intended for non-commercial fishing, but control of the take is almost non-existent and often approaches commercial levels.

Caiman poaching. The Paraguayan caiman has 


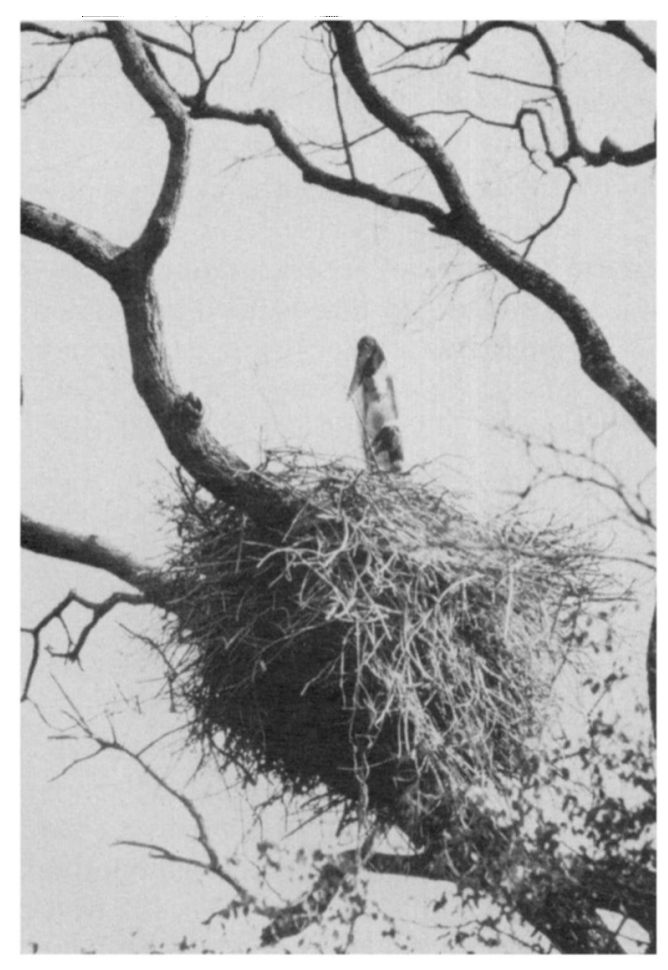

Jabiru stork on nest in the Pantanal (Russell A. Mittermeier).

an extensive range in South America (Medem, 1983). It is still found in the Brazilian portion of the Pantanal, but it is estimated that poachers take 1 million caiman skins each year (Gaski and Hemley, 1988). Approximately half of these poachers are believed to be Brazilian, and the rest Paraguayan and Bolivian. They often have high-speed motor boats, automatic weapons, aircraft, and sometimes radio support, and are far better equipped than the enforcement agencies in the region. The poaching is often directly linked with cocaine trafficking. Since the Pantanal forms a broad and largely uncontrollable border with Paraguay and Bolivia (two countries not noted for their effectiveness in controlling wildlife trade), enforcement of protective measures will continue to be very difficult. The fact that the Paraguay River is considered an international waterway further complicates matters.

A highly publicized campaign against the poachers, 'Operação Pantanal', was carried out in September 1983, involving the Army, Navy, Air Force and the Federal Police. Unfortunately, it succeeded in capturing only a small number of poachers while killing others, and impounding 15 light planes, which were later released. Many local people not necessarily involved in the trade were mistreated in the operation, and the general feeling in the region is that the exercise was largely for show and accomplished nothing of long-term value.

As a result of 'Operação Pantanal', a plan was developed to control poaching permanently in both Mato Grosso and Mato Grosso do Sul. This plan included a research programme on caiman and 18 guardposts to control the trade. It was developed in 1983 for implementation in 1984, but never received the support needed to carry it out.

A caiman skin in Brazil can cost between $\$ 1.50$ and $\$ 5.00$. Once taken to Bolivia or Paraguay, the value increases to $\$ 15.00$ $\$ 30.00$, a significant amount of money in this economically-depressed region. The situation is further complicated by the fact that captured poachers are rarely punished.

One positive sign is that large landowners in the Pantanal are starting to band together to fight against caiman poaching. In many cases this is motivated more by a desire to protect their land against intruders than by concern for the caiman, but it can be very effective.

Cattle. Cattle have been present in the Pantanal for more than a century, but intensive cattle management requiring the conversion of forest to pasture is a more recent phenomenon and a serious threat to forest animals and vegetation. Cattle trample the open savannah and the forest understorey, and their selective feeding changes the vegetation composition and also increases the number of toxic and invasive plants such as Ipomoea fistulosa, Solanum malacoxylon and Senna spp. (Prance and Schaller, 1982).

The seasonal burning of dry grass to promote new growth, usually between July and October, has a detrimental affect on small cerrado animals, depriving them of food and cover. Fire sometimes spreads into forests and 
bamboo thickets, where it has an even more disastrous effect (Schaller, 1983).

There has been concern for more than 100 years that certain diseases carried by cattle, such as brucellosis, could become epidemic and spread to deer, capybara or other susceptible fauna of the Pantanal.

There has been a steady decline in cattle ranching since 1974, when a major flood on the Paraguay River resulted in the loss of 3.5 million cattle (an estimated 28 per cent). With this decline and other economic problems that have beset Brazil, many residents of the Pantanal have had to look for other sources of income and the caiman skin trade has sometimes been an easy alternative.

Destructive tourism. According to several Brazilian colleagues, the Pantanal has become fashionable in Brazil and tourism has increased tremendously over the past 5 years. Most tourists are Brazilians who come for brief visits from large cities like São Paulo. Unfortunately, the region still has little infrastructure to support such a large flow.

Most of the tour buses that come into the region do little or nothing to teach visitors about the ecology and fragile nature of the Pantanal, its importance to Brazil and the threats to it. There are reports of tourists throwing stones at caiman, swerving on the road to hit a snake basking in the sun, and screaming loudly near a nesting area of wood storks, roseate spoonbills and egrets to scare hundreds of birds into flight at once for a photograph. In some cases, commercial fishing activities take place under the guise of tourism.

Forest destruction. The Pantanal has some extensive tracts of forest, including magnificent stands of cambará (Vochysia spp.), whose yellow flowers provide an impressive spectacle during the dry season. Unfortunately, along with the cutting of forest to make way for cattle pasture and intensive agriculture, there is now interest in turning these stands of cambará and other forests into charcoal. This is a wasteful, low-value use of an important resource, which should be prohibited before it reaches a level at which economic interests will make control politically difficult or impossible.

Hunting. Aside from caiman poaching, hunting of several other species poses a potential problem. Schaller (1983) cites hunting of capybara, six-banded and nine-banded armadillos and all ungulates as food by ranch workers and squatters, of foxes because they kill chickens, and otter and ocelot are killed for their skins. Jaguars and pumas are considered as threats as they take cattle on a regular basis in some areas. One conservation-orientated rancher estimated that he lost 150 head of cattle per year to jaguar in an area of $1000 \mathrm{sq} \mathrm{km}$. Jaguars are also shot because their skins have a high commercial value. Jaguar hunting with the traditional zagaia, a large, heavy spear, was once considered the ultimate in manly sports This method of hunting jaguar entails a great deal of risk to the hunter, and has all but disappeared, although some old-timers still have zagaias and boast of previous exploits. Capybara are sometimes killed as pests, especially when they reach high population densities and appear to compete with cattle for pasture. Tourists sometimes shoot birds, caiman or mammals from roads. On the whole subsistence game hunting for food, so common in Amazonia, is not nearly as significant a feature in the Pantanal, the residents being accustomed to eating mainly beef and fish.

In late 1988 several of the ranch-owners in the Pantanal put forward a proposal to the Brazilian Government for open hunting on some game, such as duck, jaguar and capybara, possibly a consequence of pressure from large tour operators and the economic need of some of the farmers. Since the price of beef has fallen drastically since 1984, some of the ranchers are seeking alternative sources of income.

\section{Pantanal conservation priorities}

\section{Training}

Training of conservation professionals in key 
wetland conservation activities such as caiman and capybara management, fish ecology, and ornithology, should be a high priority. It may be useful to have special workshops on management of caiman and capybara populations, given the great potential that use of these animal presents for the Pantanal. It would be beneficial for scientists particularly interested in ranching caiman and capybara to visit existing ranches for these species in Venezuela and to see the successful crocodile ranching operations in Papua New Guinea.

Training in fund-raising and administration is also essential for the new, yet growing, nongovernmental conservation organizations like the Pantanal Defense Society (SODEPAN), the Mato Grosso Ecological Association (AME), and the newly created Association for the Recuperation and Conservation of the Environment (ARCA).

Support should be given for Pantanal park directors to attend the Conservation Education Training Course for environmental educators, a programme largely funded by the World Wildlife Fund, which is aimed particu- larly at professionals working in protected areas threatened by human impact.

\section{Sustainable use of key wildlife species}

Sustainable use of species such as capybara and caiman is of potential economic importance; it could counterbalance the decline in cattle-raising and stem the illegal trade in caimans. All trade in wild species has been prohibited in Brazil since 1967, so at present any utilization programme for these animals would have to be carried out through captive breeding or as semi-captive ranching operations. Since captive breeding is expensive, ranching will probably be more appropriate. Commercial caiman farming/ranching is receiving increasing attention among Pantanal ranch-owners. Preliminary studies on caiman populations have been conducted in both Mato Grosso do Sul and Mato Grosso. However, much more study is necessary on population dynamics and nutritional requirements prior to commercial investment.

A meeting was held in March 1989 in

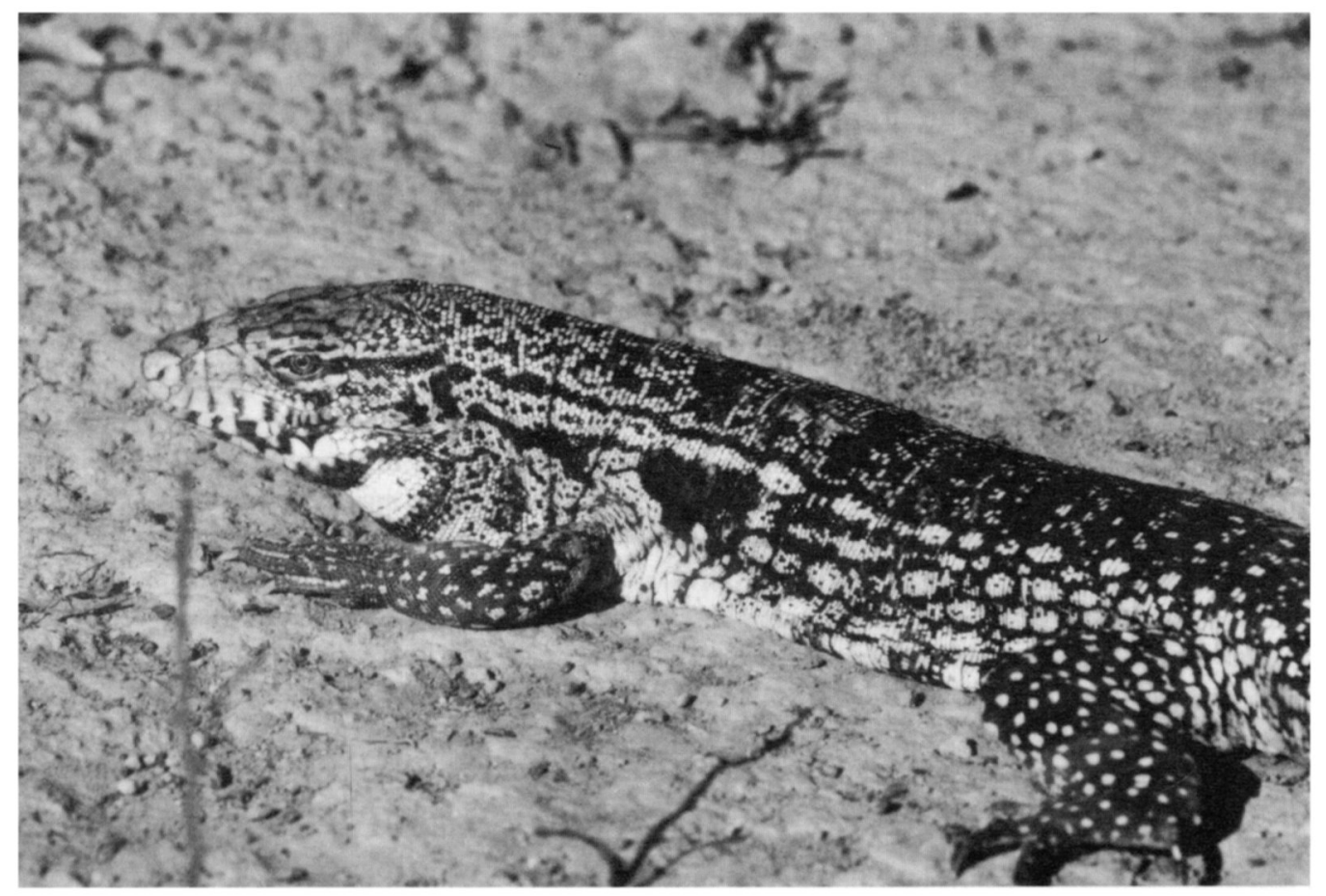

Tegu lizard, one of the many reptile species in the Pantanal (Russell A. Mittermeier). 
Campo Grande, Mato Grosso do Sul to discuss caiman poaching, law enforcement strategies, and research, and to define priorities and objectives for caiman conservation and management. Participants included representatives from the Rural Workers' Union, State Governments, Scientific Research Organizations and international conservation and wildlife regulatory agencies. There were several concrete measures for action declared, one of which is to create a private foundation directed by a council of representatives from all major conservation bodies, research institutions and universities in the Pantanal region, and IBAMA, the responsible federal agency. This foundation will be responsible for supporting a caiman research programme, developing a caiman management plan and for monitoring the illegal poaching of caiman.

Various models of utilization of crocodilian populations exist (as in Papua New Guinea, Zimbabwe and the US) and could be applicable to the Pantanal (e.g. National Research Council, 1983). However, given the size and remoteness of much of the Pantanal, the presence of two international borders and the current levels of illegal trade in caiman skins, maintenance of the integrity of a legal sustainable use programme is sure to present problems, especially at the outset. Unless there is very strict control and monitoring, illegally obtained skins and meat are likely to enter the market since they will usually be more inexpensive than those obtained through rational utilization programmes.

It is clear that much more research on the population biology of key species in the Pantanal is necessary. Little has been published even on the much-discussed caiman and capybara of the region (e.g. Crawshaw and Schaller, 1980, 1982; Schaller and Crawshaw, 1981).

Capybara meat, although occasionally eaten, is not traditionally popular throughout Brazil. The current market exists on a small scale for speciality restaurants and creating a larger market could increase pressure on wild populations and add to the many enforcement problems already in existence.

Sustainable utilization of fish in the
Pantanal could be a viable source of income, although it is a complex issue since even less information is available on fish than on capybara and caiman. The federal agency responsible for fisheries (formerly SUDEPE, now IBAMA) has shown little interest in controlling the fish industry in the Pantanal. No easy solution is in sight, but the development of cooperatives for local fishermen as well as aquaculture and strict control (or elimination) of industrial scale fisheries has been suggested. A project to study the reproductive biology of fish species, migratory strategies and key breeding sites is under way through the Pantanal Livestock and Ranching Research Center (CPAP/EMBRAPA). The data from this project will be valuable in establishing biologically based regulations for Pantanal fisheries.

\section{Development of nature tourism}

Tourism can either be a boon or a bane to the Pantanal. To date, it has not been carefully planned and local conservationists feel that it has had more of a negative effect than anything else. However, it should be possible to ensure that tourism is not destructive, and that it includes a strong educational component. Promotional materials should be provided to tour agencies and to the Mato Grosso and Mato Grosso do Sul state environmental agencies for incorporation into their programmes.

The development of hotel-fazendas by local landowners is a private initiative that would provide additional revenue for the region. High quality facilities for specialized wildlife tourists might, in the long term, even replace cattle-raising to some extent on those fazendas most suitable for wildlife watching. One such hotel-fazenda is currently operating on Estancia Caiman in Mato Grosso do Sul, an especially rich area for wildlife viewing with relatively easy access. It could serve as a model for other fazendas with similar potential.

\section{Establishment and expansion of parks and reserves}

Since so much of the Pantanal is in private hands, it is unlikely that areas will be set aside 
as federal parks and reserves. However, there is growing conservation awareness among some landowners, many of whom have a deep appreciation of wildlife and have already protected their land for years. Others are starting to become interested, mainly to prevent incursions by caiman poachers. All these people can be encouraged to play a greater role in conservation activities. The recent creation of the Pantanal Defense Society by concerned landowners is a step in the right direction, and is deserving of full support from the conservation community.

\section{Expansion of Taiamã and the Pantanal National} Park. Both the Pantanal National Park and the Taiamã Ecological Station consist almost entirely of land that is completely flooded during the wet season, and both would benefit from extensions that would provide some dry land refuge. It is difficult to envisage how this could be accomplished for the Taiamã Ecological Station, which lies in the middle of a vast flooded area. However, an increase in its size, even of permanently flooded aquatic ecosystems, would be very important.

The Pantanal National Park abuts on several drier stretches that could be incorporated into the park, namely Fazenda Acurizal, which touches on the Serra do Amolar. This additional dry land would allow for policing of illegal poaching, would facilitate tourism and would help maintain viable populations of large predators and migratory species. An attempt to obtain this $137-\mathrm{sq}-\mathrm{km}$ fazenda in 1978 was unsuccessful, but it changed hands in 1985, and the new owner appears to be sympathetic to conservation. The Pantanal National Park is also adjacent to several large tracts of cambará-dominated forest to the south. These remain dry throughout the year and would make a valuable addition to the park, if the current owners could be persuaded to sell.

Since only about 1.5 per cent of the Pantanal is currently in government parks and reserves, it would be desirable to add a number of protected areas to this network. However, this will depend on the availability and cost of appropriate land.
Estrada-parque. One author (MP) has suggested making the $125-\mathrm{km}$ Transpantaneira Highway (running from Poconé to Porto Jofre) a Highway-Park or Estrada-parque. This management category has yet to be created, but could incorporate laws prohibiting commercial over-use and use for industrial purposes and could facilitate the control of large scale, potentially destructive tourism. The State Environmental Foundation in Mato Grosso (FEMA) plans to construct a Tourist Information Centre at the start of the Transpantaneira Highway. The Centre will be used as a launching point for educational awareness tours and as a law enforcement check point.

Bird Sanctuaries. The various bird nesting sites in the Pantanal should be protected. In 1989 the Environmental Agency of Mato Grosso do Sul started a long-term research and monitoring programme for bird nesting sites in the Pantanal in that state. The data from this study will be utilized for essential education and preservation efforts in the region, through establishment of a private reserve network. Private landowners will be encouraged to participate by monitoring the bird nesting sites on their land.

\section{Species conservation projects}

Studies of endangered species are important; some are already under way, but others should be initiated.

A 3-year study to determine the status and ecological aspects of the marsh deer population in the southern Pantanal began in 1989 through CPAP/EMBRAPA. Objectives include determining population size and regional distribution, population structure, nutritional and habitat requirements, the effects of hunting, predation and cattle disease on the population, and competition between marsh deer and cattle for available food resources.

A species protection plan must be developed for the Pantanal jaguar with particular consideration given to the maintenance of genetic viability and use of corridors (including important riparian habitats) to do so. The 
plan should include research on why ranchers kill jaguar so that solutions to this problem can be achieved. Ranchers should be encouraged to improve cattle ranching practices, and to set aside areas for jaguar reserves.

A long-term study started in August 1989 on the diversity, distribution and abundance of birds in the state of Mato Grosso. The project co-ordinators will work closely with FEMA to provide information so that a conservation plan for birds can be developed.

\section{Education and public awareness}

Education and public awareness are essential components of any long-term conservation programme. Brazilians in general, and especially those living in the states of Mato Grosso do Sul and Mato Grosso, need to be made aware of the importance of the Pantanal, both as a national wildlife heritage and as a resource for the future. People living in the Pantanal must be encouraged to adopt economic activities that are sustainable over the long term. People living in the vicinity of rivers that flow into the Pantanal must be taught to use the land wisely, and to avoid erosion, siltation and pollution by agrotoxins, detergents and heavy metals. With the proper approach, the Pantanal can become a rallying point for conservation throughout the states of Mato Grosso and Mato Grosso do Sul. The interest in conservation that is likely to result will benefit not just the Pantanal but other ecosystems in these states.

In addition to the increasing interest in the Pantanal on the part of the Brazilian governmental and non-governmental organizations, the World Bank has also become concerned about conservation in the region. A major component on the Pantanal region has been included in the World Bank Environmental Loan currently under discussion. It is hoped that this international attention will stimulate
Brazil to make a further investment in conservation.

\section{References}

Alho, C., Lacher, T. and Goncalves, H. 1988. Environmental degradation in the Pantanal ecosystem. BioScience, 38, 165.

Crawshaw, P.G., Jr and Schaller, G.B. 1980. Nesting of Paraguayan caiman (Caiman yacare) in Brazil. Papeis Dep. Zool. S Paulo 33, 282-292.

Crawshaw, P. G., Jr and Schaller, G.B. 1982. Fishing behaviour of Paraguayan caiman (Caiman crocodilus). Copeia, (1), 66-72.

Gaski, A. and Hemley, G. 1988. The ups and downs of the crocodilian skin trade. WWF-TRAFFIC Newsletter, 8, (1),14.

Medem, F. 1983. Los Crocodylia de Sur America. Vol, II. Colciencias, Bogota, Colombia.

National Research Council. 1983. Crocodiles as a Resource for the Tropics. National Academy Press, Washington, DC.

Prance, G.T. and Schaller, G.B. 1982. Preliminary study of some vegetation types of the Pantanal Mato Grosso, Brazil. Brittonia, (342), 228-251.

Schaller, G.B. 1983. Mammals and their biomass on a Brazilian Ranch. Archos Zool. Est S Paulo, 31, 1-36.

Schaller, G.B. and Crawshaw, P.G. Jr. 1981. Social organization in a capybara population. Sonderdruck aus Saugetierkundliche Mitteilungen BLV Verlagsgesellschaft $m b H$, Munchen 40, 29 Jhg. Heft 1, 3-16.

Sick, H. 1983. Migracoes de Aves na America do Sul Continental. Publicacao technica (2) CEMAVE, Brasilia, Brazil.

Russell A. Mittermeier, President, Conservation International, 1015 18th St., NW, Washington DC 20036, USA, and Department of Anatomical Sciences, School of Medicine, Health Sciences Center, State University of New York at Stony Brook, Stony Brook, New York 11794-8081, USA.

Ibsen de Gusmão Camara, Av. das Americas 2300, Casa 40, 22640 Rio de Janeiro-RJ, Brazil

Maria Tereza Jorge Pádua, Fundacao Pro Natureza, Caixa Postal 02-0186, 70.001 Brasilia, DF, Brazil. Janice Blanck, WWF, 1250 Twenty-Fourth Street, NW, Washington DC 20037, USA. 